\title{
Identification of pathogenesis pathway in basal-like breast cancer based on mutant p53 protein and topoisomerase-II $\alpha$ expression
}

\author{
Yayi Dwina, Ria Kodariah, Endang S.R. Hardjolukito \\ Department of Anatomical Pathology, Faculty of Medicine, Universitas Indonesia, Jakarta, Indonesia
}

\begin{abstract}
Abstrak
Latar belakang: Keganasan kanker payudara jenis basal-like sulit untuk diterapi dengan regimen terapi standar karena tidak mengekspresikan reseptor hormon atau reseptor faktor pertumbuhan epidermis yang menjadi target terapi. Diperlukan upaya identi ikasi molekul yang berperan pada karsinoma payudara jenis basal-like, terutama molekul yang dapat dijadikan target pengobatan, salah satunya topoisomerase II y yang diregulasi oleh protein p53. Penelitian bertujuan untuk membandingkan ekspresi protein p53 mutan dan topoisomerase-IIa pada karsinoma payudara basal-like dan non basal-like, serta menentukan hubungan antara ekspresi protein p53 mutan dan topoisomerase-II $\alpha$ pada kelompok basal-like.
\end{abstract}

Metode: Sampel 40 blok parafin karsinoma payudara yang sudah terverifikasi triple negative, dibagi menjadi 2 kelompok berdasarkan ekspresi cytokeratin - 5 (CK-5) yaitu kelompok karsinoma payudara jenis basal-like dan non basal-like. Ekspresi p53 mutan dan Toposiomerase-IIa diperiksa dengan imunohistokimia, kemudian dihitung dan dibandingkan pada kedua kelompok. Analisis statistik untuk analisis deskriptif, kappa test, uji normalitas, perbandingan dua mean dan kategori menggunakan SPSS versi 16.

Hasil: Median (min-max) ekspresi p53 mutan pada kelompok basal-like adalah 21 (0-100), kelompok non basal-like 2 (0-80), $p=0,061$. Min-max ekspresi topoisomerase IIa pada kelompok basal-like 263 (15492), kelompok non basal-like 262 (0-481), $p=0,409$. Ditemukan hubungan bermakna antara positifitas p53 mutan dengan subtipe karsinoma payudara $(p=0,027)$. Terdapat pula koekspresi yang lebih sering p53 mutan topoisomerase II $\alpha$ pada basal-like dibandingkan dengan non basal-like $(p=0,018)$.

Kesimpulan: p53 mutan dan topoisomerase-IIa secara bersama-sama dapat berperan dalam salah satu jalur patogenesis karsinoma payudara jenis basal-like.

\begin{abstract}
Background: Basal-like breast cancer is difficult to treat with standard regimen therapy, because it doesn't express hormone receptors or epidermal growth factor receptors. Identification of oncogenesis pathway is expected to find molecules which can be used as target for therapy. One candidate molecule is topoisomerase-II $\alpha$ whose expression is regulated by $\mathrm{p} 53$. This study aimed to compare the expression of mutant p53 proteins and topoisomerase II $\alpha$ in basal-like and non basal-like breast cancer, and to determine the association between mutant p53 proteins and topoisomerase II $\alpha$ in basal-like group.
\end{abstract}

Methods: The samples were 40 formalin fixed paraffin embedded tissues from verified triple negative breast cancer tissue. The samples were divided into 2 groups, basal-like and non basal-like breast cancer, based on cytokeratin - 5 (CK-5) expression. Mutant p53 proteins and topoisomerase II $\alpha$ were stained using immunohistochemistry method, scored and compared. Statistical test used SPSS software version 16 for descriptive statistics, kappa test, normality test, comparison of two mean, and categorical comparison.

Results: Median (min-max) of mutant p53 protein expression in basal-like group was $21(0-100)$, the non basal-like group was $2(0-80), p=0.061$. Min-max of topoisomerase II $\alpha$ in basal-like group was 263 (15-492), non basal-like group was $262(0-481), \mathrm{p}=0.409$. There was an association between mutant p53 positivity with breast cancer subtype $(\mathrm{p}=0.027)$ and between mutant $\mathrm{p} 53$-topoisomerase II $\alpha$ coexpression with breast cancer subtype $(\mathrm{p}=0.018)$.

Conclusion: Co-expression of mutant p53 with topoisomerase II $\alpha$ has the role in one of the pathway of basal-like breast cancer pathogenesis.

Keywords: basal-like breast cancer, mutant p53, topoisomerase-II $\alpha$

pISSN: 0853-1773• eISSN: 2252-8083 • http://dx.doi.org/10.13181/mji.v23i4.995 • Med J Indones. 2014;23:197-202

Correspondence author: Yayi Dwina, yayidwina@yahoo.com

Copyright@2014 Authors. This is an open access article distributed under the terms of the Creative Commons Attribution-NonCommercial-ShareAlike 4.0 International License (http://creativecommons.org/licenses/by-nc-sa/4.0/), which permits unrestricted non-commercial use, distribution, and reproduction in any medium, provided the original author and source are properly cited. 
Breast cancer is the most common malignancy in women worldwide. In developing country the prevalence continues to increase and often diagnosed at an advanced stage. ${ }^{1}$ Breast cancer has heterogeneous clinical, pathological, histological, molecular, and response to treatment characteristics. In order to better understand and to find the appropriate treatment strategy for this disease, various attempts have been made to classify breast cancer. $^{2}$

Based on the expression of its mRNA, breast cancer is divided into 5 types: luminal A, luminal B, normal breast like, human epidermal growth factor receptor 2 (HER2) positive, and basal-like. ${ }^{3,4}$ Basallike type has the most aggressive clinical behavior and poor prognosis. Basal-like breast cancer often do not express estrogen (ER), progesterone (PR) and HER2 receptors, hence triple negative breast cancer terminology. ${ }^{5}$ This type of breast cancer also frequently express high molecular weight cytokeratins, such as cytokeratin - 5 (CK-5). In other word, basal-like breast cancer is triple negative breast cancer that express high molecular weight cytokeratins. ${ }^{5}$ The non-expression of ER, PR, and HER2 in basal-like breast cancer is link to difficulties in therapy, because targeted therapy using standard hormone receptor with HER2 as its target, will not work. ${ }^{5}$ Therefore it is necessary to explain the characteristic of basal-like breast cancer, so that we will be able to explain the aggressiveness, and to find the potential molecule involved and hence design the right treatment.

In basal-like breast cancer, there are several known genetic defects, such as decreased expression of breast cancer genes 1 (BRCA1), ${ }^{4,5}$ a genes responsible for repair of deoxyribose-nucleic acid (DNA) double stranded break. ${ }^{5}$ The high amount of DNA double stranded breaks in normal cells causes cell cycle stalled; but basal-like breast cancer seems to have high tolerance for BRCA1 defect, and cell cycle keep going on despite the high accumulation of DNA damage. This resistance is hypothetically caused by mutations in the p53 gene, a tumor suppressor gene. In a p53-gene-mutated-cell the cell cycle will not be interrupted even if there has been a significant defect in DNA. ${ }^{5,6}$

One protein in which transcription is regulated by p53 is topoisomerase II $\alpha .^{7,8}$ Topoisomerase II $\alpha$ is an ubiquitous enzyme in the cell nucleus, which plays a role in the regulation of DNA topology. ${ }^{7,9}$
It also regulate many biological processes such as replication, segregation, transcription, regulation of chromatin structure and general gene expression..$^{10,11}$ Wang, et $\mathrm{al}^{7}$ and Sandri, et $\mathrm{al}^{8}$ in in vitro study has proved that topoisomerase II $\alpha$ gene expression can be inhibited by p53 gene, even though the mechanisms is not completely understood.

These studies raised possibilities that pathogenesis of basal-like breast cancer could be mediated by pathway that involve the p53 gene and topoisomerase II $\alpha$, in which p53 tumor suppressor gene dysfunction causing increase expression of topoisomerase II $\alpha$.

Topoisomerase II $\alpha$ is one of the molecular targets for chemotherapy, but the prognosis has not improved significantly. ${ }^{12}$ There are also several side effects caused by anti-topoisomerase II $\alpha$ regimen such as secondary malignancies as well as cardiotoxicity Therefore, ideally the regiment should only be given to cancer patients with positive topoisomerase II $\alpha .{ }^{13}$ It is important to study oncogenesis pathways of $\mathrm{p} 53$-topoisomerase II $\alpha$. If this pathway proves important in the pathogenesis of basal-like breast cancer then it could serve as the basis/justification for the treatment of breast cancer with a regimen targeting topoisomerase II $\alpha$.

\section{METHODS}

Ethical clearance was obtained from Institutional Review Board (IRB) of the Faculty of Medicine Universitas Indonesia. The study was conducted in the Immunopathology Laboratory Department of Anatomical Pathology Faculty of Medicine Universitas Indonesia, during January to December 2011. The study used 40 triple negative breast cancer tissues from formalin fixed paraffin embedded preparation. The samples were stained using automated immunostainer with three markers: CK-5, mutant p53, and topoisomerase II $\alpha$. For CK-5 (Rabbit anti CK-5, Biocare, dilution 1/100) and topoisomerase II $\alpha$ (mouse anti topoisomerase II $\alpha$, DakoCytomation, dilution 1/500) we use machine-automated Benchmark XT immunostainer VENTANA with paraffin protocol. For staining of mutant p53 we used primary antibody mouse monoclonal anti-human p53 protein Clone DO-7 (DakoCytomation) 1:1500 dilution. Positive controls for each antibody were included using previously established positively stained tissue. The negative control from each case was also included. 
Cell was categorized as positive for CK-5 if demonstrated cytoplasmic and membrane staining. ${ }^{14}$ The semi-quantitative assessments was as follows: negative if $<10 \%$ of tumor cells show positive results, positive if $\geq 10 \%$ of tumor cells show positive results. Mutant p53 positive cell was nuclear stained cell and scored using proportion of 100 cells count, and categorized as positive if more than $10 \%$ showed positive result, and negative if less than $10 \% .^{15}$

Topoisomerase II $\alpha$ was positive if showed nuclear staining and scored by counting the positivity based on 500 cells count using $400 \mathrm{x}$ magnification. ${ }^{11}$ It was grouped as negative if $<25 \%$ tumor cells show positive results, positive if $\geq 25 \%$ tumor cells show positive results.

The assessment of immunohistochemistry staining was done by two independent pathologists and the results were analyzed by Kappa test. Statistical test was using SPSS software version 16 for descriptive statistics, kappa test, normality test, comparison of two mean, and categorical comparison.

\section{RESULTS}

Forty two confirmed triple negative cases were obtained, among which 2 cases were excluded due to minimal amount of tumor tissue. Of the 40 cases, 20 cases were positive for CK-5 so it was grouped as the basal-like breast cancer, and the other 20 cases were negatively stained with CK-5 and were grouped as the non basal-like breast cancer. Assessment of mutant p53, topoisomerase II and CK-5 was performed by two independent pathologists, the kappa values were as followed: kappa values for mutant $\mathrm{p} 53=0.866, \mathrm{p}$ $<0.001$; kappa values for topoisomerase II $\alpha=1, \mathrm{p}=$ 0.002; kappa values for CK-5 $=0.879, \mathrm{p}<0.001$; all showed good concordance.

Table 1. Median score of topoisomerase II $\alpha$ and mutant p53 expression in basal-like breast cancer and non basal-like breast cancer

\begin{tabular}{|c|c|c|c|}
\hline \multirow[b]{2}{*}{ Marker expression } & \multicolumn{2}{|c|}{ Type of breast cancer } & \multirow[b]{2}{*}{$\mathrm{p}^{*}$} \\
\hline & $\begin{array}{c}\text { Non basal- } \\
\text { like }(\mathrm{n}=20)\end{array}$ & $\begin{array}{c}\text { Basal-like } \\
(\mathrm{n}=20)\end{array}$ & \\
\hline
\end{tabular}

\begin{tabular}{lccc}
$\begin{array}{l}\text { Topoisomerase II } \alpha \\
\text { median (min - max) }\end{array}$ & $262(0-481)$ & $263(15-492)$ & 0.409 \\
$\begin{array}{l}\text { Mutant p53 } \\
\text { median (min - max) }\end{array}$ & $2(0-80)$ & $21(0-100)$ & 0.061 \\
\hline
\end{tabular}

*Mann-Whitney
Table 1. is about the median score of Topoisomerase $\mathrm{II} \alpha$ and mutant p53 expression in basal-like breast cancer and non basal-like breast cancer, it showed there was no difference in the expression of Topoisomerase II $\alpha$ and mutant p53 between two groups.

Table 2. showed positivity of Topoisomerase II $\alpha$ and mutant p53 in basal-like breast cancer and non basal-like breast cancer, in this table we can see there was an association between mutant p53 expression and the type of breast cancer, in the basal-like group mutant p53 expressed more often compared to non basal-like group.

Table 3. is about the correlation between expression of mutant p53 and Topoisomerase II $\alpha$ in basal-like breast cancer, it showed that there was co-expression of mutant p53 and topoisomerase II $\alpha$ in half of

Table 2. Positivity of topoisomerase II $\alpha$ and mutant p53 in basal-like breast cancer and non basal-like breast cancer

\begin{tabular}{lccc}
\hline & $\begin{array}{c}\text { Basal-like } \\
\mathrm{n}(\%)\end{array}$ & $\begin{array}{c}\text { Non basal-like } \\
\mathrm{n}(\%)\end{array}$ & $\mathrm{p}^{*}$ \\
\hline $\begin{array}{l}\text { Topoisomerase II } \alpha \text { expression } \\
\text { Positive }\end{array}$ & $15(75 \%)$ & $12(60 \%)$ & 0.311 \\
$\quad$ Negative & $5(25 \%)$ & $8(40 \%)$ & \\
$\begin{array}{l}\text { Mutant p53 expression } \\
\text { Positive }\end{array}$ & & \\
Negative & $13(65 \%)$ & $6(30 \%)$ & 0.027 \\
\hline
\end{tabular}

*Chi-square

Table 3. The correlation between expression of mutant p53 and topoisomerase II $\alpha$ in basal-like breast cancer

\begin{tabular}{|c|c|c|c|}
\hline \multirow{2}{*}{ Mutant p53 } & \multicolumn{2}{|c|}{ Topoisomerase II $\alpha$} & \multirow{2}{*}{$\mathrm{p}^{*}$} \\
\hline & Positive n (\%) & Negative $\mathrm{n}(\%)$ & \\
\hline Positive & $10(50 \%)$ & $3(15 \%)$ & 0.727 \\
\hline Negative & $5(25 \%)$ & $2(10 \%)$ & \\
\hline
\end{tabular}

*Mc Nemar

Table 4. Proportion of p53 mutant-topoisomerase II $\alpha$ co-expression in basal-like breast cancer and non basal-like breast cancer

\begin{tabular}{lccc}
\hline & $\begin{array}{c}\text { Mutant } \mathrm{p} \\
\text { 53-topoisomerase II } \alpha \\
\text { co-expression n (\%) }\end{array}$ & $\begin{array}{c}\text { Mutant } \mathrm{p} \\
\text { 53-topoisomerase II } \alpha\end{array}$ & $\mathrm{p}^{*}$ \\
non co-expression n (\%) & \\
\hline $\begin{array}{l}\text { Basal- } \\
\text { like }\end{array}$ & $10(50 \%)$ & $10(50 \%)$ & 0.018 \\
$\begin{array}{l}\text { Non } \\
\text { basal-like }\end{array}$ & $3(15 \%)$ & $17(85 \%)$ & \\
\hline
\end{tabular}

*Chi-square 

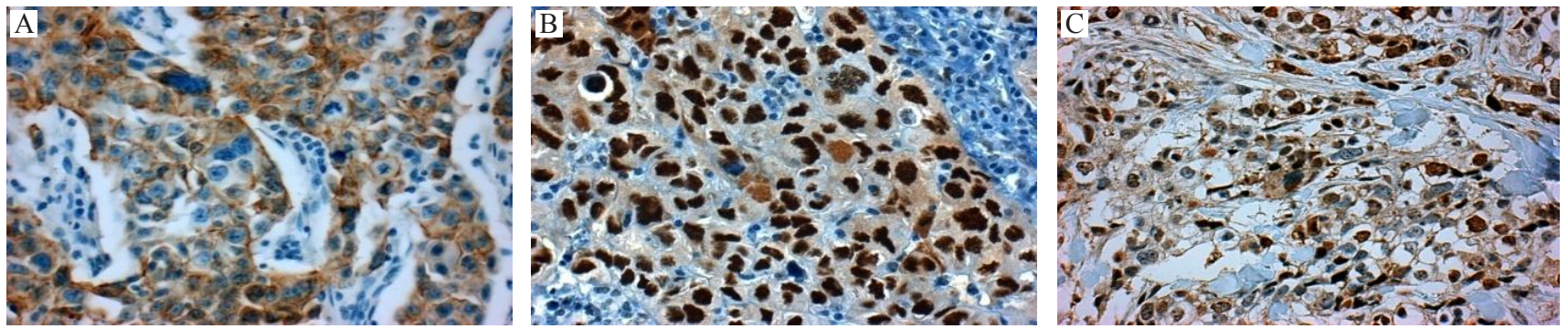

Figure 1. Immunohistochemistry A) CK-5 brown color in the membrane and cytoplasm; B) Mutant p53 protein, it shows positivity as brown color in the nuclei; C) Topoisomerase II $\alpha$, the positivity is represented by brown color in the nuclei

the basal-like cases, but there was no significant difference between mutant p53 and topoisomerase II $\alpha$ expression in the whole cases of basal-like breast cancer.

Table 4. showed proportion of p53 mutanTopoisomerase II $\alpha$ co-expression in basal-like breast cancer and non basal-like breast cancer, in this table we can see there was significant difference in coexpression mutant p53-topoisomerase II $\alpha$ between basal-like breast cancer (50\%) and the non basal-like breast cancer (15\%).

Figure 1 showed the positivity of CK-5, mutant p53, and topoisomerase II $\alpha$, immunohistochemistry in breast cancer tissues.

\section{DISCUSSION}

In this study the positive expression of mutant p53 in basal-like breast cancer (65\%) was higher than that of the non-basal-like (30\%). This is in line with Conforti, et $\mathrm{a}^{16}$ who found $51 \%$ positivity of mutant p53 in basal-like breast cancer, while in the non-basal like the positivity was only $11 \%$. The explanation for this phenomenon was that as much as $80 \%$ $90 \%$ basal-like breast cancer were associated with reduced expression of BRCA $1 .{ }^{17} \mathrm{BRCA} 1$ is a protein that has a role in various cellular processes such as response to DNA damage repair, control check points in the cell cycle, transcription modulation, and ubiquitinisation. ${ }^{5,6,18}$ In normal condition cells with reduced levels BRCA1, either due to mutation or promoter's methylation should undergo cessation of the cell cycle and eventually death. In basal-like breast cancer it seems that the tumor cells are not responding to the lack of BRCA1 levels so that the cell cycle continue. This phenomenon might be caused by mutation of the tumor suppressor gene p53, allowing genetically defective cells to continue replicating and eventually transforming into cancer cells. ${ }^{2,5,6}$ This explanation is consistent with the results of the study by Holstege, et $\mathrm{al}^{6}$ who found that all breast cancers with BRCA1 expression defects were also contained p53 mutations, while other studies found $60 \%-77 \%$ p53 mutations in breast carcinoma with BRCA1 defects. ${ }^{6}$

No difference was found in topoisomerase II $\alpha$ expression between basal-like breast cancer and the non basal-like, although the basallike group has slightly higher positivity $(75 \%)$, compared to non basal-like (60\%). This finding is actually consistent with the results reported by Romero, et $\mathrm{al}^{19}$ They stated that topoisomerase II $\alpha$ protein expression which was measured by immunohistochemistry method, was higher in the basal-like breast carcinoma $(72.72 \%)$, compared with the other subtypes: luminal type B (57.14\%), HER2 positive (62.5\%), luminal A $(9 \%)$, and normal-like $(0 \%)$.

This study also assessed the relationship between mutant p53 expressions with topoisomerase II $\alpha$ expression in basal-like breast cancer; although we didn't find any significant association, but it showed that mutant p53-topoisomerase II $\alpha$ co-expressed in half of cases. This didn't explain the hypothesis of mutant p53 and topoisomerase II $\alpha$ role in basal-like breast canacer. There might be other carcinogenesis pathway involved in the pathogenesis of basallike breast cancer. They were: epidermal growth factor receptor (EGFR), proto-oncogene c-kit (c-KIT), and BRCA $1 .{ }^{5}$ Another possibility was that the biological trait of topoisomerase II $\alpha$ doesn't expressed continuously in the cell cycle. The highest expression is in late $\mathrm{S}$ phase and peaked in growth2 - mitosis (G2-M) phase. ${ }^{20}$ Because of this feature topoisomerase II $\alpha$ considered as cell proliferation surrogate marker, and doesn't expressed in the cell constantly, ${ }^{19}$ instead it depends on the cell cycle status. $^{21}$ 
The non association between mutant p53 and topoisomerase II $\alpha$ may be caused by the method used to assess p53 status. In this study we used immunohistochemistry to detect the presence of mutant p53, because mutant p53 have longer halflife than the wild type variant, according to literature. Half-life of wild-type p53 is very short and it's basically expressed in a very small amount below the detection threshold of immunohistochemistry. ${ }^{22,23}$ Sjogren, et $\mathrm{al}^{24}$ stated that mutant $\mathrm{p} 53$ detection using immunohistochemistry produce false positive results as much as $30 \%$ and false-negative results around $33 \%$ when compared to measurements using copy dna (cDNA) sequencing. It was mentioned that increased expression of p53 by immunohistochemistry standard methods can represent mutations in the p53; verification using cDNA sequencing are considered as gold standard. ${ }^{22}$ False positive staining by immunohistochemistry method can be due to cellular stress induced p53 wild-type stabilization, Whereas the incidence of false negatives may occur due to mutation causing stop codons, deletions, or mutation causing destabilization of the protein. ${ }^{25}$ Truncation at the carboxyl end of p53 could cause false negative result, since the truncated mutant $\mathrm{p} 53$ protein will be degraded due to lost of several important function, for example the function for DNA binding domain, nuclear localization signals, and oligomerization domain $^{24}$

We also assess the relationship between type of breast carcinoma with the incident of topoisomerase II $\alpha$ mutant p53 co-expression, and it revealed significant results with $\mathrm{p}=0.018$. Half of basal-like breast cancer showed topoisomerase II $\alpha$-mutant p53 coexpression, which is higher than the co-expression in non basal-like group which only expressed in 3 samples $(15 \%)$. This supports the hypothesis of mutant p53 and topoisomerase II $\alpha$ involvement in basal-like breast cancer pathogenesis. According to Wang, et $\mathrm{al}^{7}$ and Sandri, et $\mathrm{al}^{8} \mathrm{p} 53$ has the ability to regulate topoisomerase II $\alpha$ expression, in in-vitro studies they found that $\mathrm{p} 53$ has the ability to regulate topoisomerase II $\alpha$ transcription, by interacting with topoisomerase promoter $(-32$ to +90$)$ in dna sequence cytosine cytosine adenine adenine tyrosine (CCAAT) segments. Wild-type p53 can act as a transacting elements capable of suppressing transcription of topoisomerase II $\alpha$, while mutant p53 has less ability to suppressed topoisomerase II $\alpha$ expression. This finding can also serve as the consideration for treatment planning using anti topoisomerase II $\alpha$ drug in part of basal like breast cancer.
In conclusion, this study showed a significant association between mutant p53 expression and basal like subtype. There was no association between $\mathrm{p} 53$ and topoisomerase II $\alpha$ expression in basal like group. Co-expression of mutant p53topoisomerase II $\alpha$ occurred significantly more often in basal like, which indicates the role of mutant p53-topoisomerase II $\alpha$ pathway in basal like pathogenesis in part of cases.

\section{Conflicts of interest}

The authors affirm no conflict of interest in this study.

\section{Acknowledgments}

We would like to thank Professor Santoso Cornain, and Mr. Kusmardi for their invaluable contribution in statistical analysis of this study, and also dr. Vinesia Lestari Riddi for allowing authors to continue using her samples and her work in the basal like breast cancer.

\section{REFERENCES}

1. World Health Organization [Internet]. Breast cancer: prevention and control. Breast cancer. [updated 2008; cited 2010 Dec 20]. Available from: http://www.who.int/cancer/ detection/breastcancer/en/

2. Rakha E, Reis-Filho JS. Basal like breast carcinoma from expression profiling to routine practice. Arch Pathol Lab Med. 2009;133(6):860-8.

3. Lester SC. The breast. In: Kumar V, Abbas AK, Fausto N, Aster JC, editors. Robbins and Cotran pathologic basis of disease. $8^{\text {th }}$ ed. Philadelphia, PA: Sauders Elseviers; 2010. p. 1065-96.

4. Perou CM, Sørlie T, Eisen MB, van de Rijn M, Jeffrey SS, Rees CA, et al. Molecular portraits of human breast tumours. Nature. 2000;406(6797):747-52.

5. Rakha E, Reis-Filho JS, Ellis IO. Basal-like breast cancer: a critical review. J Clin Oncol. 2008;26(15):2568-81.

6. Holstege H, Joosse SA, van Oostrom CT, Nederlof PM, de Vries A, Jonkers J. High Incidence of protein truncating TP53 mutations in BRCA-1 related breast cancer. Cancer Res. 2009;69(8):3625-33.

7. Wang Q, Zambetti GP, Suttle DP. Inhibition of DNA topoisomerase II $\alpha$ gene expression by the p53 tumor suppressor. Mol Cell Biol. 1997;17(1):389-97.

8. Sandri MI, Isaacs RJ, Ongkeko WM, Harris AL, Hickson ID, Broggini M, et al. p53 regulates the minimal promoter of the human topoisomerase II $\alpha$ gene. Nucleic Acids Res. 1996;24(22):4464-70.

9. Roca J. Survey and summary topoisomerase II: a fitted mechanism for the chromatin landscape. Nucleic Acid Res. 2009;37(3):721-30.

10. Nitiss JL. DNA topoisomerase II and its growing repertoire of biological function. Nat Rev Cancer. 2009;9(5):327-37. 
11. Hellemans P, van Dam PA, Geyskens M, van Oosterom AT, Buytaert P, Van Marck E. Immunohistochemical study of topoisomerase II- $\alpha$ ekspression in primary ductal carcinoma of the breast. J Clin Pathol. 1995;48(2):147-50.

12. Sørlie T, Perou CM, Tibshirani R, Aas T, Geisler S, Johnsen $\mathrm{H}$, et al. Gene expression patterns of breast carcinomas distinguish tumor subclasses with clinical implications. Proc Natl Acad Sci USA. 2001;98(19):10869-74.

13. Nitiss JL. Targeting DNA topoisomerase II in cancer chemotherapy. Nat Rev Cancer. 2009;9(5):338-50.

14. Dogu GG, Ozkan M, Ozturk F, Dikilitas M, Er O, Ozturk A. Triple-negative breast cancer: immunohistochemical correlation with basaloid markers and prognostic value of survivin. Med Oncol. 2010;27(1):34-9.

15. Lukas J, Niu N, Press MF. p53 mutations and expression in breast carcinoma in situ. Am J Pathol. 2000;156(1):183-91.

16. Conforti R, Boulet T, Tomasic G, Spielmann M, Delaloge $\mathrm{S}$, Arriagada R, et al. Predictive value of MRP2, p53, bcl2 and topoisomerase II immunostainings for the efficacy of anthracyclines-based adjuvant chemotherapy in breast cancer: Results from two randomized trials. J Clin Oncol (Meeting Abstracts). 2008;26(15 Suppl):616.

17. Turner NC, Reis-Filho JS, Russell AM, Springall RJ, Ryder $\mathrm{K}$, Steele D, et al. BRCA1 dysfunction in sporadic basallike breast cancer. Oncogene. 2007;26(14):2126-32.

18. Ahmed M, Lalloo F, Evans DG. Update on genetic predisposition to breast cancer. Expert Rev Anticancer Ther. 2009;9(8):1103-13.
19. Romero A, Martín M, Cheang MC, López García-Asenjo JA, Oliva B, He X, et al. Assessment of topoisomerase II $\alpha$ status in breast cancer by quantitative PCR, gene expression microarrays, immunohistochemistry, and fluorescence in situ hybridization. Am J Pathol. 2011:178(4):1453-60.

20. Woessner RD, Mattern MR, Mirabelli CK, Jhonson RK, Drake FH. Proliferation- and cell cyle-dependent differences in expression of the 170 kilodalton and 180 kilodalton forms of topoisomerase II in NIH-3T3 cells. Cell Growth Differ. 1991;2(4):209-14.

21. Moelans CB, de Weger RA, van Blokland MT, van der Wall E, van Diest PJ. Simultaneous detection of TOP2A and HER2 gene amplification by multiplex ligationdependent probe amplification in breast cancer. Mod Pathol. 2010;23(1):62-70.

22. Vojtěsek B, Bártek J, Midgley CA, Lane DP. An immunochemical analysis of the human nuclear phosphoprotein p53 new monoclonal antibodies and epitope mapping using recombinant p53. J Immunol Methods.1992:151(1-2):237-44.

23. Cooper K, Haffajee Z. bcl-2 and p53 protein expression in follicular lymphoma. J Pathol. 1997;182(3):307-10.

24. Sjögren S1, Inganäs M, Norberg T, Lindgren A, Nordgren $\mathrm{H}$, Holmberg L, et al. The p53 gene in breast cancer: prognostic value of complementary DNA sequencing versus immunohistochemistry. J Natl Cancer Inst. 1996;88(3-4):173-82.

25. N, Triaspolitica. "Kanker Payudara: Informasi, Penyebab, Gejala, Stadium Dan Pengobatan." Mau Nanya Dong Dok. N.p, 28 June 2017. Web. 30 June 2017. <https:// nanyadongdok.blogspot.com/2017/06/kanker-payudarainformasi-penyebab.html>. 